\title{
Calcium/Calmodulin-mediated Action of Calcitonin on Lipid Metabolism in Rats
}

\author{
Yoshiki Nishizawa, Yasuyuki Okui, Masaaki Inaba, Senji Okuno, Kazuhiko Yukioka, \\ Takami Miki, Yoshio Watanabe, ${ }^{\star}$ and Hirotoshi Morii \\ Second Department of Internal Medicine, Osaka City University Medical School, Abeno, Osaka 545, Japan; \\ and *Institute for Experimental Animals, Kobe University School of Medicine, Kobe 650, Japan
}

\begin{abstract}
The effects of calcitonin on lipid metabolism were investigated in three kinds of rats, one strain of rabbits, and a primary culture of rat hepatocytes. In a short-term experiment, calcitonin decreased serum cholesterol and triglycerides after injection in rats on either an ordinary or high-fat diet. In a longterm experiment, calcitonin decreased the serum cholesterol and triglycerides in uremic rats, hypothalamic obese rats, and Watanabe-heritable hyperlipidemic rabbits. In cultured hepatocytes, calcitonin reduced the incorporation of $\left[{ }^{14} \mathrm{Clacetate}\right.$ into cholesterol and triglycerides in a dose-dependent way. Treatment with $W 7$, a calmodulin inhibitor, overcame the decrease caused by calcitonin in serum lipids in rats and in the synthesis of triglycerides from acetate or palmitate in the hepatocytes, but did not alter the intracellular cAMP level or incorporation of $\left[{ }^{32} \mathrm{P}\right] \mathrm{Pi}$ into $\mathrm{PI}$ in the cells. The results suggest that calcitonin lowers serum lipid levels and lipogenesis in hepatocytes in a calcium/calmodulin-dependent way.
\end{abstract}

\section{Introduction}

Factors affecting lipid metabolism are usually classified as exogenous or endogenous. Exogenous factors include dietary factors, exercise, and iatrogenic factors. Endogenous factors include genetic factors and enzyme or hormonal disturbances. Of the hormones, especially peptide hormones, that affect lipid metabolism, insulin, glucagon, gonadotropin, growth hormone, adrenocorticotropic hormone, and so on, are known to have physiological or pharmacological significance. It has come to be believed that PTH and calcitonin may also participate in lipid metabolism.

PTH stimulates lipolysis in vitro $(1,2)$ and in vivo (3) and elevates the level of cholesterol in experimental animals $(4,5)$. Parathyroidectomy decreases the level of cholesterol in patients with chronic renal disease $(6,7)$. These studies suggest that PTH affects lipid metabolism. Calcitonin gene-related peptide (CGRP), ${ }^{1}$ which is biosynthesized by alterations in the

Address reprint requests to Dr. Yoshiki Nishizawa, Second Department of Internal Medicine, Osaka City University Medical School, 1-5-7, Asahi-machi, Abeno-ku, Osaka 545, Japan.

Received for publication 6 October 1987 and in revised form 4 April 1988.

1. Abbreviations used in this paper: CGRP, calcitonin gene-related peptide; CM, chylomicrons; Pi, inorganic phosphate; PI, phosphatidyinositol; VMH, ventromedial hypothalamus; W5, $N$-(6-aminohexyl)-1-naphthalenesulfonamide; W7, $N$-(6-aminohexyl)-5-chloro-1naphthalenesulfonamide/ $\mathrm{HCl}$.

J. Clin. Invest.

(c) The American Society for Clinical Investigation, Inc. 0021-9738/88/10/1165/08 \$2.00

Volume 82, October 1988, 1165-1172 processing of RNA transcripts from the calcitonin gene, seems to resemble calcitonin in its action. However, CGRP is not identical to calcitonin in either its action or receptor sites (8-10). There are contradictory reports about the liver receptor for CGRP. One group found specific binding in liver (11), another did not (12). The effect of CGRP on lipid metabolism has been speculated upon, but not clearly identified. Calcitonin inhibits the lipolysis induced by PTH in rat epididymal adipose tissues (13). Calcitonin causes glycogenolysis and affects amino acid metabolism in the liver $(14,15)$, and also affects the metabolism of calcium and phosphate (16-18). Zucker rats with genetic obesity have a high concentration of calcitonin in their serum (19) and pituitary (20). These animals are also hyperlipoproteinemic (21), so calcitonin might have a pathophysiological significance in the disordered lipid metabolism of these rats. These results suggest the possibility that calcitonin is involved in lipid metabolism.

Together, the findings indicate that calcitonin affects lipid metabolism. In the in vivo part of this study, four experimental models of hyperlipidemia were examined to check the effect of calcitonin administration on the serum level of lipids. In the in vitro part of the study, a primary culture of rat hepatocytes was used to investigate the effect of calcitonin on lipogenesis in the liver.

\section{Methods}

\section{General protocol}

In vivo study. The effect of calcitonin injections on lipid levels was evaluated in $(a)$ rats fed a high-fat diet, $(b)$ uremic rats, $(c)$ rats after the destruction of the ventromedial hypothalamus (VMH rats), which caused hypothalamic obesity, and $(d)$ Watanabe-heritable hyperlipidemic (WHHL) rabbits.

In vitro study. The effect of calcitonin was examined in rat hepatocytes by measurement of lipogenesis, intracellular cAMP, and incorporation of $\left[{ }^{32} \mathrm{P}\right]$ inorganic phosphate $(\mathrm{Pi})$ into phosphatidylinositol $(\mathrm{PI})$, and by treatment beforehand with a calmodulin inhibitor, W7.

\section{Animals}

We used 6-wk-old male Sprague-Dawley rats as the control rats and for the high-fat study, 4-wk-old male Wistar rats for the uremia experiment, and 6-wk-old female Sprague-Dawley rats for the study of hypothalamic obese rats. All rats were obtained from Shizuoka Laboratory Animal Center, Hamamatsu, Japan. WHHL rabbits (22) were supplied by Dr. Yoshio Watanabe, Kobe University School of Medicine, Kobe, Japan. The rats and rabbits were fed regular laboratory chow (22.9\% protein, $6.0 \%$ fat, $7.5 \%$ carbohydrates, $9.5 \%$ fiber, $6.3 \%$ ash, and 47.8\% other; Oriental Yeast Co., Ltd., Tokyo, Japan) or a high-fat diet for high-fat feeding in rats $(21.2 \%$ protein, $60 \%$ fat, $5.0 \%$ carbohydrates, $4.0 \%$ fiber, $3.6 \%$ ash, and $6.2 \%$ other, expressed as a percentage per weight; Oriental Yeast Co., Ltd.). Tap water was available ad lib.

\section{Experimental procedures}

Study of high-fat diet. Rats were put on a high-fat diet for 3 wk starting when they were $6 \mathrm{wk}$ old, and were bled $1-4 \mathrm{~h}$ after the subcutaneous 

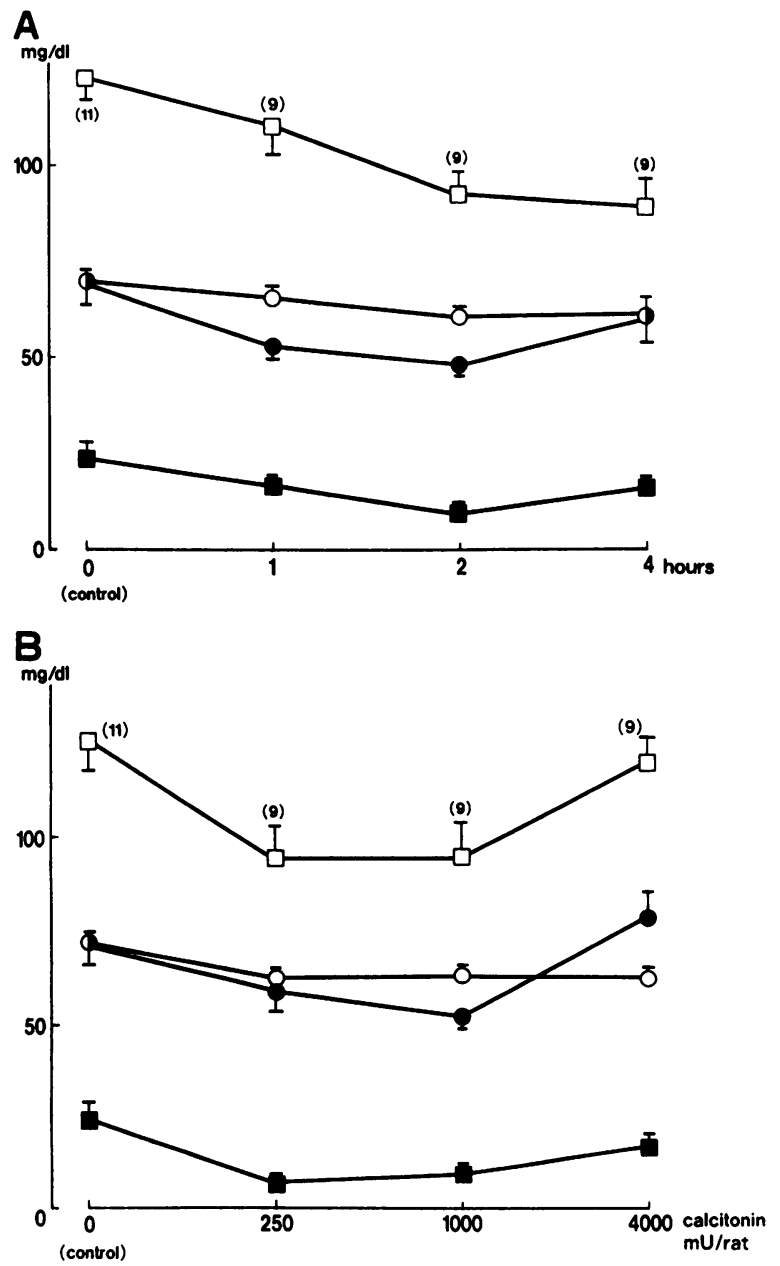

Figure 1. Levels of serum lipids and lipoproteins after a single injection of calcitonin in rats fed a high-fat diet. $(A)$ Changes with a 1,000-mU/rat dose of calcitonin. LDL, VLDL, cholesterol, and triglycerides (TG) were significantly decreased until $4 \mathrm{~h}$, according to analysis of variance $(P<0.01,<0.05,<0.05$, and $<0.05$, respectively). (B) Dose-response effect of calcitonin $2 \mathrm{~h}$ after injection. LDL, VLDL, cholesterol, and TG were significantly decreased with calcitonin until the $4,000-\mathrm{mU} / \mathrm{rat}$ dose $(P<0.01,<0.01,<0.05$, and $<0.05$, respectively). $\circ$, cholesterol; $\bullet$, TG; $\square$, LDL; $\bullet$, VLDL.

injection of calcitonin (synthetic salmon calcitonin; Teikoku Hormone Mfg. Co., Ltd., Tokyo, Japan) at the doses of 250-4,000 $\mathrm{mU} / \mathrm{rat}$.

Study of uremic rats. Partially ( $87 \%$ or five sixths) nephrectomized rats were used as an experimental model of uremia. At the age of $5 \mathrm{wk}$, two thirds of one kidney was removed. 1 wk later, the other kidney was removed completely (23). Starting $10 \mathrm{~d}$ after the second operation, calcitonin was injected subcutaneously three times a week at the dose of $0.5,5$, or $50 \mathrm{mU} / \mathrm{rat}$ for $12 \mathrm{wk}$. $1 \mathrm{~d}$ after the last injection of calcitonin, the rats were starved overnight, and their blood was sampled the next day.

Study of hypothalamic obese rats. VMH lesions were produced by a constant anodal current of $2 \mathrm{~mA}$ (Stoelting Co., Chicago, IL) passed for $20 \mathrm{~s}$ through a stainless-steel electrode insulated except for the tip. The coordinates were as described before $(24,25)$. Calcitonin was injected subcutaneously starting $1 \mathrm{wk}$ after the VMH lesions were made, five times a week for 4 wk at the dose of 50 or $250 \mathrm{mU} / \mathrm{kg}$ body wt. $1 \mathrm{~d}$ after the last injection, the rats were starved overnight and their blood was sampled.

WHHL rabbits. One male and one female WHHL rabbit, both 8 mo old, each were injected with calcitonin three times a week for 12 wk at the dose of 250 and $1,000 \mathrm{mU} / \mathrm{kg}$ body wt, respectively. Blood was sampled before the injection and at 2,4 , and $24 \mathrm{~h}$ after each injection in weeks 1,8 , and 12 .

Hepatocyte isolation and monolayer culture. Parenchymal hepatocytes were isolated from male Sprague-Dawley rats that had been given regular chow ad lib. The cells were isolated by in situ perfusion of the liver with collagenase (26). They were suspended at $5 \times 10^{5}$ cells $/ \mathrm{ml}$ in William's medium E, containing $10 \% \mathrm{FCS}, 10^{-5} \mathrm{M}$ dexamethasone, and $2 \times 10^{-9} \mathrm{M}$ insulin, and cultured at the density of $10^{5} \mathrm{cells} / \mathrm{cm}^{2}$ in plastic dishes (Falcon Labware, Becton, Dickinson \& Co., Oxnard, CA) in a humidified chamber at $37^{\circ} \mathrm{C}$ under $5 \% \mathrm{CO}_{2}$ and $30 \% \mathrm{O}_{2}$ in the air. Cell viability was usually $>90 \%$ as measured by a trypan blue exclusion test. After culture for $6 \mathrm{~h}$, the medium was changed; it was changed daily thereafter.

Assay of lipogenesis. Monolayers of hepatocytes in 35-mm dishes were incubated with $1.5 \mathrm{ml}$ of Hanks' solution containing $5 \mathrm{mM}$ Hepes, $5 \mathrm{mM}$ sodium $\left[1-{ }^{14} \mathrm{C}\right]$ acetate $(1 \mu \mathrm{Ci} / \mathrm{ml}$, Amersham International, Amersham, UK), and $2.94 \times 10^{-7}-2.9 \times 10^{-4} \mathrm{M}$ calcitonin for 2 or $4 \mathrm{~h}$. The cells were washed twice with Hanks'-Hepes solution, and dissolved in $0.5 \mathrm{~N} \mathrm{NaOH}$. The lipids in the product were extracted with petroleum ether, and the extract was evaporated under $\mathrm{N}_{2}$ (27). The concentrated extract was dissolved in a small volume of ethylether spotted on Silica Gel 60 plates (E. Merck, Darmstadt, FRG), and developed with $n$-hexane/ethylether/acetic anhydride, 70:20:1 (vol/ $\mathrm{vol} / \mathrm{vol}$ ). Spots were located with iodine vapor and scraped off into vials and then the radioactivity was counted (27).

Assay of intracellular CAMP. After culture of the hepatocytes with $2.94 \times 10^{-5} \mathrm{M}$ calcitonin and $10^{-9} \mathrm{M}$ glucagon in Hanks'-Hepes solution with or without $10 \mathrm{mM}$ theophylline for 3-20 min, the cells were washed twice with PBS and then homogenized in $0.1 \mathrm{~N} \mathrm{HCl}$. The

\section{A}
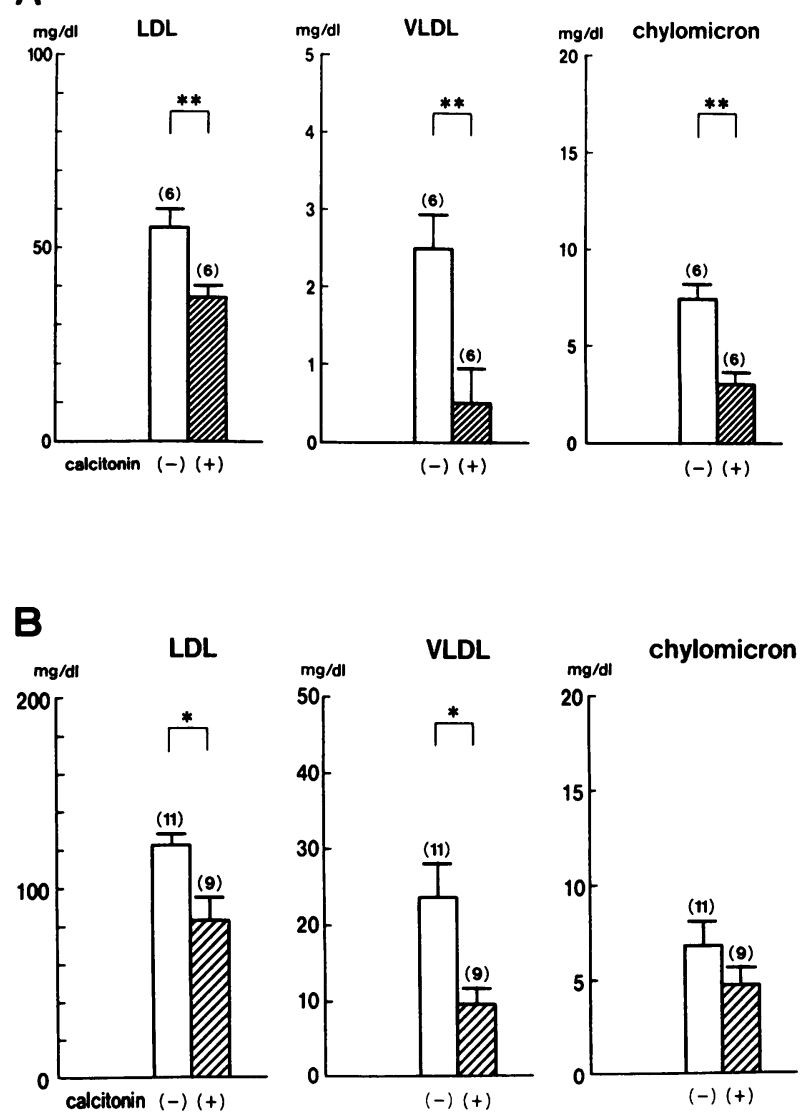

Figure 2. Levels of serum lipoproteins $2 \mathrm{~h}$ after a single injection of calcitonin at the dose of $1,000 \mathrm{mU} / \mathrm{rat}$. (A) Rats given regular chow. (B) Rats given a high-fat chow. ${ }^{*} P<0.05$, and ${ }^{* *} P<0.025$ by $t$ test. 
Table I. Effect of Calcitonin on Serum Cholesterol and Triglycerides in Rats with Chronic Renal Failure

\begin{tabular}{|c|c|c|c|c|c|}
\hline & \multicolumn{4}{|c|}{ Daily dose of calcitonin } & \multirow{3}{*}{$\begin{array}{l}\text { Significance } \\
\text { by analysis } \\
\text { of variance }\end{array}$} \\
\hline & \multicolumn{4}{|c|}{$m U / r a t$} & \\
\hline & 0 & 0.5 & 5 & 50 & \\
\hline$n$ & 10 & 10 & 10 & 10 & \\
\hline BUN & & & & & \\
\hline$(m g / d l)$ & $35.9 \pm 4.6$ & $33.1 \pm 2.9$ & $36.8 \pm 4.8$ & $28.3 \pm 2.4$ & NS \\
\hline $\begin{array}{c}\text { Cholesterol } \\
(m g / d l)\end{array}$ & $82.2 \pm 5.7$ & $90.1 \pm 8.6$ & $70.4 \pm 5.5$ & $66.6 \pm 4.5$ & $P<0.05$ \\
\hline Triglycerides & & & & & \\
\hline$(m g / d l)$ & $66.3 \pm 9.8$ & $44.8 \pm 4.8$ & $46.0 \pm 4.3$ & $24.2 \pm 2.8$ & $P<0.01$ \\
\hline
\end{tabular}

Calcitonin was injected subcutaneously three times a week for 12 wk. $n=$ number of rats in each group. BUN, blood urea nitrogen. Values are expressed as means $\pm \mathrm{SE}$.

cAMP assay was done with a cAMP-RIA kit (Yamasa Shoyu Co., Ltd., Choshi, Japan).

Assay of $P I$. The cells were incubated in 10-cm dishes with $3.0 \mathrm{ml}$ of medium containing $132 \mathrm{mM} \mathrm{NaCl}, 2.7 \mathrm{mM} \mathrm{KCl}, 1.0 \mathrm{mM} \mathrm{MgSO}_{4}, 1.8$ $\mathrm{mM} \mathrm{CaCl}_{2}, 5.6 \mathrm{mM}$ glucose, $0.1 \% \mathrm{FCS}, 20 \mathrm{mM}$ Hepes (pH 7.2), and [ $\left.{ }^{32} \mathrm{P}\right] \mathrm{Pi}(50 \mu \mathrm{Ci} / \mathrm{ml}$, Amersham International) for $60 \mathrm{~min}$. After the cells were washed twice with PBS they were harvested and centrifuged. Chloroform/methanol (1:2, vol/vol) was added to the pellet, and lipids were extracted by evaporation of the solvent mixture under $\mathrm{N}_{2}$ gas. Then the concentrated extract was spotted on Silica Gel 60 plates and developed by two-dimensional chromatography with chloroform/ methanol/13.3 M ammonium (65:35:5.5, vol/vol/vol) and then with chloroform/acetone/methanol/acetate $(3: 4: 1: 0.5, \mathrm{vol} / \mathrm{vol} / \mathrm{vol} / \mathrm{vol})$. Spots were made visible with iodine vapor and scraped off into vials; then the radioactivity was counted (28).

Study of calmodulin inhibitor. For some of the rats on the high-fat diet, $N$-(6-aminohexyl)-5-chloro-1-naphthalenesulfonamide/ $\mathrm{HCl}$ (W7) was injected intraperitoneally $1 \mathrm{~h}$ before an injection of calcitonin at the dose of $1 \mathrm{mg} / \mathrm{rat}$. In the study of hepatocytes, W7 was added to the concentration of 5-10 $\mu \mathrm{M} 1 \mathrm{~h}$ before the addition of calcitonin. $N$-(6-Aminohexyl)-1-naphthalenesulfonamide (W5) is a drug with less calmodulin-antagonizing effect than $W 7$ but with the same cytotoxicity. W7 and W5 were dissolved in distilled water at the
Table II. Effect of Calcitonin on Serum Lipids in VMH Rats

\begin{tabular}{lcccc}
\hline & \multicolumn{3}{c}{ Dose of calcitonin } & \\
\cline { 2 - 4 } & \multicolumn{3}{c}{$m U /$ rat } & $\begin{array}{c}\text { Significance by } \\
\text { analysis of } \\
\text { variance }\end{array}$ \\
\hline$n$ & 0 (vehicle) & 50 & 250 & \\
$\begin{array}{c}\text { Body weight } \\
(g)\end{array}$ & 7 & 8 & 6 & NS \\
$\begin{array}{c}\text { Cholesterol } \\
(m g / d l)\end{array}$ & $88.0 \pm 6.5$ & $64.6 \pm 3.4^{*}$ & $64.8 \pm 5.0^{*}$ & $P<0.01$ \\
$\begin{array}{c}\text { Triglycerides } \\
(m g / d l)\end{array}$ & $90.8 \pm 14.6$ & $44.3 \pm 6.3^{\ddagger}$ & $86.4 \pm 22.7$ & $0.05<P<0.1$
\end{tabular}

Calcitonin was injected subcutaneously five times a week for 6 wk. ${ }^{*} P<0.025$ and ${ }^{\ddagger} P<0.01$ compared with VMH rats injected with vehicle by multiple comparison (Scheffe type). The dose of calcitonin is expressed as the daily dose. $n=$ number of rats in each group. Values are expressed as means $\pm \mathrm{SE}$.

concentration of $5 \mathrm{mM}$. W7 was injected at the same concentration and distilled water was injected for the control rats.

The results are expressed as means $\pm \mathrm{SE}$. They were analyzed by use of the unpaired $t$ test for evaluation of the significance compared with controls and by multiple comparison (Scheffe type). Significance of dose relationships, time relationships, and the interaction of drugs was calculated by analysis of variance.

\section{Results}

Effect of calcitonin on serum levels of lipids. In rats on a highfat diet, a single injection of calcitonin at the dose of 1,000 $\mathrm{mU} / \mathrm{rat}$ decreased the serum cholesterol level. The same tendency was true for serum triglycerides. Lipoproteins were also significantly decreased by this treatment (Fig. $1 \mathrm{~A}$ ). With 250 $\mathrm{mU} / \mathrm{rat}$, cholesterol had decreased significantly compared with the control by $2 \mathrm{~h}$ after the injection. The decrease at this time with $4,000 \mathrm{mU} / \mathrm{rat}$ also was significant. With $250 \mathrm{mU} / \mathrm{rat}$, triglycerides tended to decrease at $2 \mathrm{~h}$ (Fig. $1 B$ ). These findings indicated that a single injection of calcitonin at the dose of
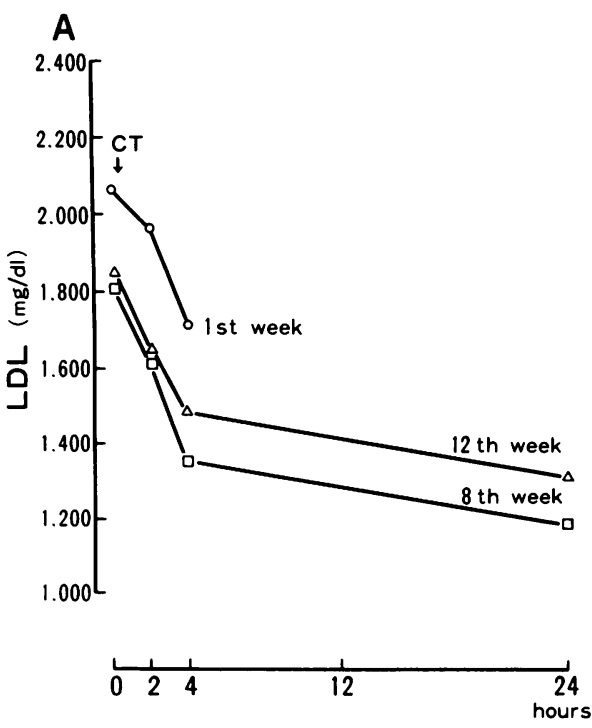
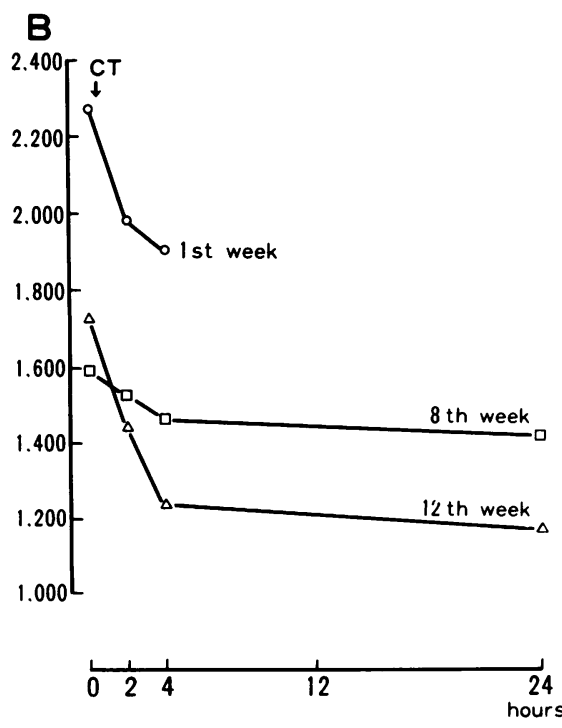

Figure 3. Effect of calcitonin on the changes in serum levels of LDL in two WHHL rabbits. Calcitonin was injected three times a week for 12 wk. $(A)$ 8-mo-old female WHHL rabbit given $1,000 \mathrm{mU} / \mathrm{kg}$ body wt calcitonin each time. $(B)$ 8-mo-old male WHHL rabbit given $250 \mathrm{mU} / \mathrm{kg}$

body wt calcitonin each time. 


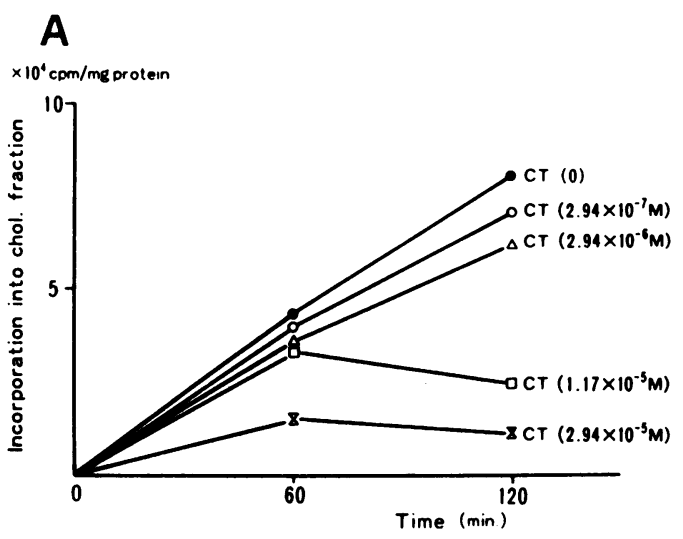

B
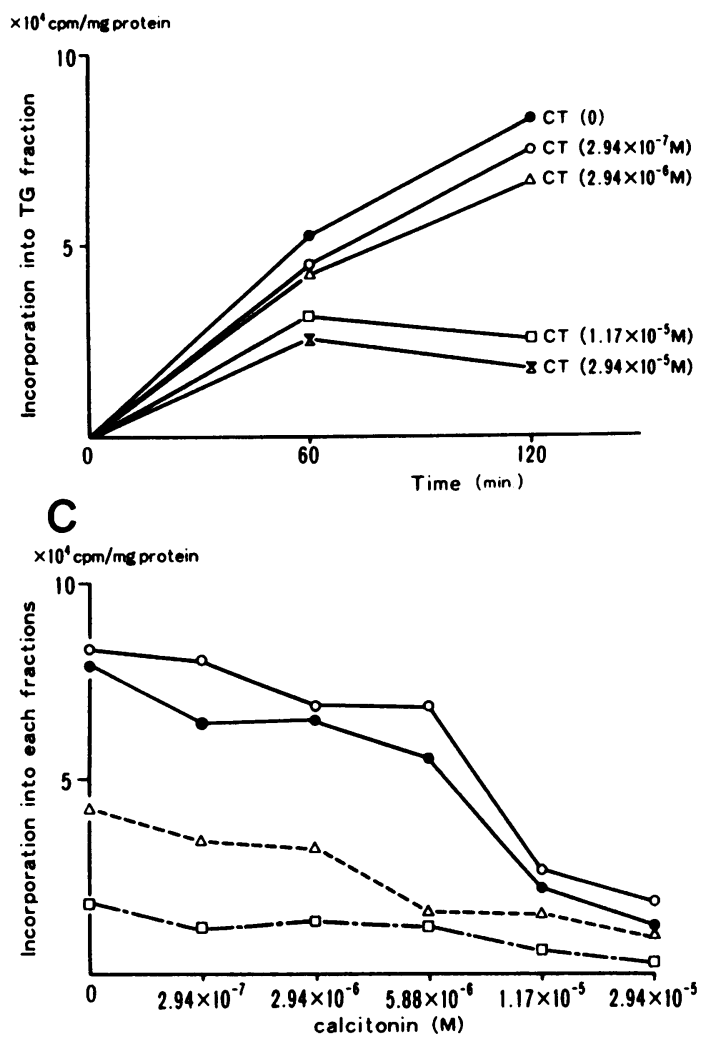

Figure 4. Effect of calcitonin on synthesis of $(A)\left[{ }^{14} \mathrm{C}\right]$ cholesterol or $(B)$ triglycerides (TG) from $\left[{ }^{14} \mathrm{C}\right]$ acetate in rat hepatocytes. $(C)$ The dose effect of calcitonin on the synthesis of cholesterol (๑), TG (0), cholesterol ester ( $\square$ ), and FFA $(\Delta)$ was assayed after $2 \mathrm{~h}$ of incubation. Values were by triplicate assays. CT, calcitonin.

$1,000 \mathrm{mU} /$ rat decreased the serum level of lipids measured $2 \mathrm{~h}$ later. Calcitonin after one injection into control rats or rats on the high-fat diet had the effects shown in Fig. 2.

The long-term effect of calcitonin was investigated by use of multiple injections in experimental animals. Regular injections of calcitonin for 12 wk significantly decreased the levels of cholesterol $(P<0.05)$ and triglycerides $(P<0.01)$ to the daily dose of $50 \mathrm{mU} / \mathrm{rat}$ in the uremic rats (Table I). The calcitonin did not affect the food intake or body weight in VMH rats, in which cholesterol and triglycerides in serum decreased when the dose of $50 \mathrm{mU} / \mathrm{kg}$ body wt was injected three times weekly for 4 wk $(P<0.025$ and $<0.01$, respectively; Table II). Calcitonin decreased LDL for $24 \mathrm{~h}$ in the
WHHL rabbit given one dose of 250 or $1,000 \mathrm{mU} / \mathrm{kg}$, and the same effect was seen with three injections a week, because LDL was lower at weeks 8 and 12 than at the baseline levels (Fig. 3).

Effect of $W 7$ on the decrease of lipids by calcitonin. The injection of $\mathrm{W} 7 \mathrm{l} \mathrm{h}$ before the injection of calcitonin did not inhibit the decreases in FFA and chylomicrons (CM), but did prevent the decreases in both LDL and triglycerides (Table III). These findings suggested that W7 suppressed the action of calcitonin and that its suppression was somehow concerned with the calcium/calmodulin mechanism.

Effect of calcitonin on lipogenesis in the rat hepatocytes. The incorporation of $\left[{ }^{14} \mathrm{C}\right]$ acetate into cholesterol was reduced by the addition of calcitonin in a dose-dependent way at 60 and $120 \mathrm{~min}$ (Fig. $4 \mathrm{~A}$ ). The incorporation of $\left[{ }^{14} \mathrm{C}\right]$ acetate into triglycerides was inhibited in the same way (Fig. $4 \mathrm{~B}$ ), as was the incorporation of $\left[{ }^{14} \mathrm{C}\right]$ acetate into FFA and cholesterol ester (Fig. $4 C$ ). The findings showed that calcitonin suppressed the synthesis of lipids in hepatocytes.

Effect of calcitonin on intracellular cAMP levels. $10^{-9} \mathrm{M}$ glucagon increased cAMP in the hepatocytes measured at 3 min, and gave more than three times that value when $10 \mathrm{mM}$ theophylline was present. Calcitonin alone at $2.94 \times 10^{-5} \mathrm{M}$ did not increase cAMP, nor did it do so when theophylline was present (Fig. $5 \mathrm{~A}$ ). The level of cAMP was monitored for up to 20 min of incubation, but calcitonin did not increase it with or without theophylline (Fig. $5 \mathrm{~B}$ ).

Effect of calcitonin on PI turnover. Vasopressin increased the incorporation of $\left.{ }^{32} \mathrm{P}\right] \mathrm{Pi}$ into $\mathrm{PI}$ at $4.71 \times 10^{-7} \mathrm{M}$ for 60 $\min (P<0.01)$, but calcitonin did not increase the incorporation at either $3.85 \times 10^{-6}$ or $3.85 \times 10^{-5} \mathrm{M}(9,623 \pm 428 \mathrm{cpm} /$ $\mathrm{mg}$ protein for the vehicle, $9,188 \pm 542 \mathrm{cpm} / \mathrm{mg}$ protein for $3.85 \times 10^{-6} \mathrm{M}$ calcitonin, $11,307 \pm 566 \mathrm{cpm} / \mathrm{mg}$ protein for $3.85 \times 10^{-5} \mathrm{M}$ calcitonin, and $25,262 \pm 432 \mathrm{cpm} / \mathrm{mg}$ protein for vasopressin, by triplicate assays). The results suggested that calcitonin did not enhance the incorporation of $\left[{ }^{32} \mathrm{P}\right] \mathrm{Pi}$ into $\mathrm{PI}$ in hepatocytes.

Effect of calcium ion in the medium on lipogenesis. The incorporation of $\left[{ }^{14} \mathrm{C}\right]$ acetate into cholesterol or triglycerides was decreased by calcitonin in medium both with calcium ion and without (Fig. 6). The inhibition caused by calcitonin of such incorporation into cholesterol and into triglycerides was exactly the same, so the difference between the lipogenesis in medium with $1.2 \mathrm{mM}$ calcium and that in calcium-free me-

Table III. Effect of Calcitonin and W7 on Lipids in Rats on a High-Fat Diet

\begin{tabular}{lccccc}
\hline \multicolumn{1}{c}{ Group } & $n$ & LDL & TG & \multicolumn{1}{c}{ FFA } & CM \\
\hline & \multicolumn{5}{c}{$m g / d l$} \\
Control & 8 & $151 \pm 11$ & $209 \pm 16$ & $1.99 \pm 0.20$ & $103 \pm 12$ \\
CT & 9 & $111 \pm 8^{*}$ & $118 \pm 6^{*}$ & $1.10 \pm 0.03^{*}$ & $48 \pm 5^{*}$ \\
W7 & 8 & $165 \pm 13$ & $198 \pm 27$ & $1.88 \pm 0.29$ & $88 \pm 24$ \\
CT + W7 & 8 & $182 \pm 22$ & $233 \pm 43$ & $1.30 \pm 0.11^{*}$ & $55 \pm 11^{*}$
\end{tabular}

W7 was injected at the dose of $1 \mathrm{mg} / \mathrm{rat}$ intraperitoneally before the subcutaneous injection of $1,000 \mathrm{mU} /$ rat calcitonin (CT). Animals were bled $2 \mathrm{~h}$ after the injection of calcitonin (means $\pm \mathrm{SE}$ ). Significance of interaction between $\mathrm{CT}$ and $\mathrm{W} 7$ by analysis of variance: LDL, $P<0.05$; TG, $P<0.05$, FFA, NS; CM, NS. 
A

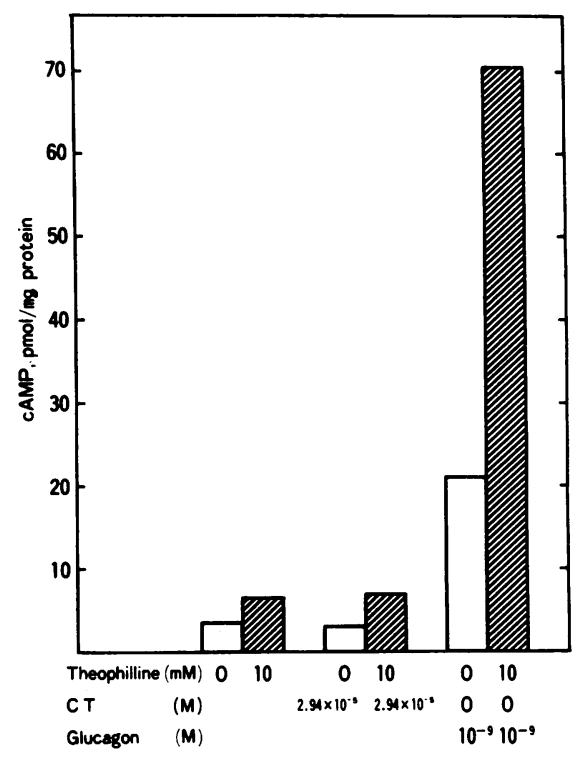

B

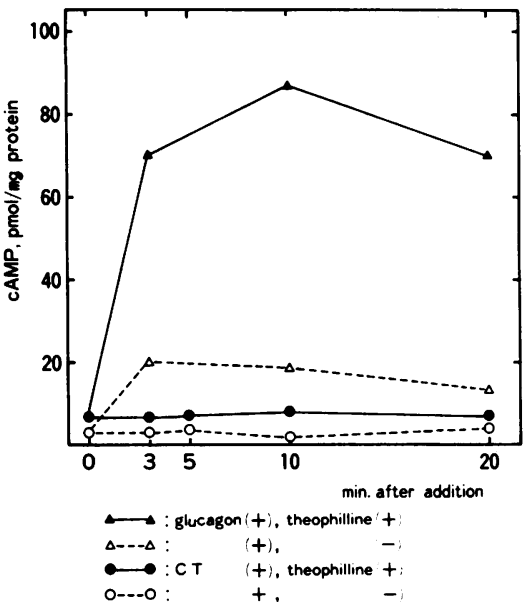

Figure 5. (A) Effect of calcitonin on intracellular levels of cAMP in rat hepatocytes with 3 min of incubation. $(B)$ Course of calcitonin effect on intracellular cAMP. Values were by triplicate assays. dium when calcitonin was not added was taken to be the lipogenesis dependent on calcium ion. The difference between lipogenesis in calcium-free medium without calcitonin and that with calcitonin is the lipogenesis independent of calcium in the medium.

Effect of $W 7$ on lipogenesis decreased by calcitonin. The incorporation of $\left[{ }^{14} \mathrm{C}\right]$ acetate into cholesterol was significantly decreased by calcitonin when W5 was added before the calcitonin, but did not decrease significantly when $\mathrm{W} 7$ was added before calcitonin (Fig. $7 \mathrm{~A}$ ). There was no significant interaction between calcitonin and $\mathrm{W} 7$ in the synthesis of cholesterol. The incorporation into triglycerides from $\left[{ }^{14} \mathrm{C}\right]$ acetate and $\left[{ }^{14} \mathrm{C}\right]$ palmitate was significantly decreased by calcitonin when W5 was added before the calcitonin, but not when W7 was added. Significant interactions were found between calcitonin

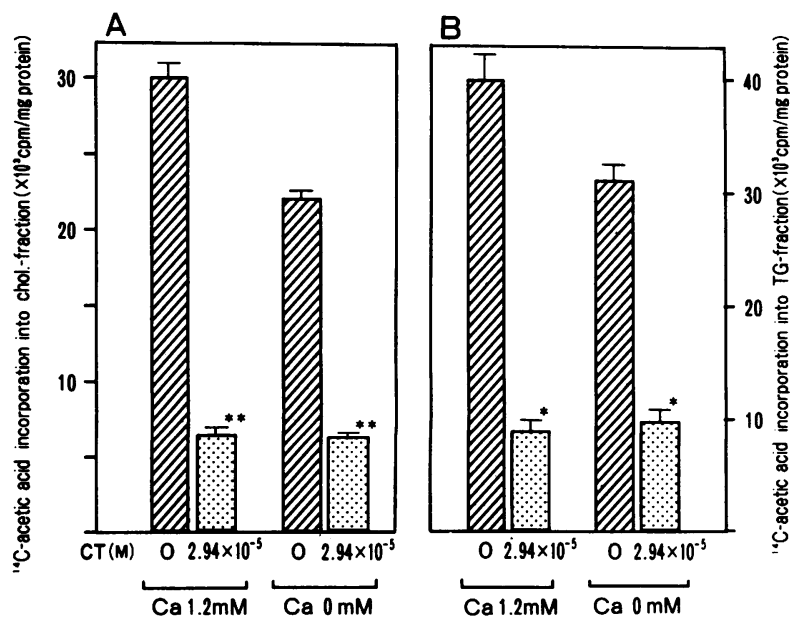

Figure 6. Effect of calcium ion in the medium on lipogenesis of rat hepatocytes in the presence or absence of calcitonin. ${ }^{*} P<0.05$ and ${ }^{* *} P<0.025$ compared with the control by $t$ test. Values were by triplicate assays. and $\mathrm{W} 7$ in the synthesis of triglycerides from acetate and from palmitate (Fig. $7 B$ and Fig. 8).

\section{Discussion}

These experiments examined the effects of calcitonin on lipid metabolism. The in vivo experiments showed that calcitonin decreased serum cholesterol and triglycerides, which are the main components of LDL and VLDL, respectively, in models of hyperlipidemia caused by different mechanisms in experimental animals: uremic rats, hypothalamic obese rats, rats on a high-fat diet, and WHHL rabbits. In the uremic rats, the main cause of hyperlipidemia is probably peripheral impairment of the removal of lipids from the blood, possibly because of the lowered metabolic turnover of VLDL caused by the suppression of lipoprotein lipase $(29,30)$, abnormalities in the protein parts of the lipoproteins (31), and decreased hepatic lipase (32). In the hypothalamic obese rats, hyperlipidemia arises from hyperinsulinemia because of decreased activity of the sympathetic nerve and increased activity of the vagus nerve after the destruction of the ventromedial nucleus of the hypothalamus, which induces hyperphagia, increased lipogenesis, and suppressed lipolysis (33-35). A high-fat diet consisting of $60 \%$ fat causes obesity and hyperlipidemia because of the increased exogenous lipids and increased lipogenesis without hyperinsulinemia $(36,37)$. In the WHHL rabbits, removal of LDL from the blood is disturbed because of the genetic deficit of LDL receptors $(38,39)$.

For uremic rats, there are two possible explanations for the calcitonin-induced hypolipidemic effect. Calcitonin may facilitate the removal of lipids peripherally, and it may inhibit lipogenesis. The first reason is a likely one, because calcitonin is effective within 1 or $2 \mathrm{~h}$ in rats on a high-fat diet. That calcitonin decreases LDL in WHHL rabbits suggests that the effect is mediated by a pathway independent of LDL receptors. The second reason is also likely because calcitonin is effective in VMH rats with hyperlipidemia mainly caused by increased lipogenesis. In the rats on the high-fat diet, treatment with W7 

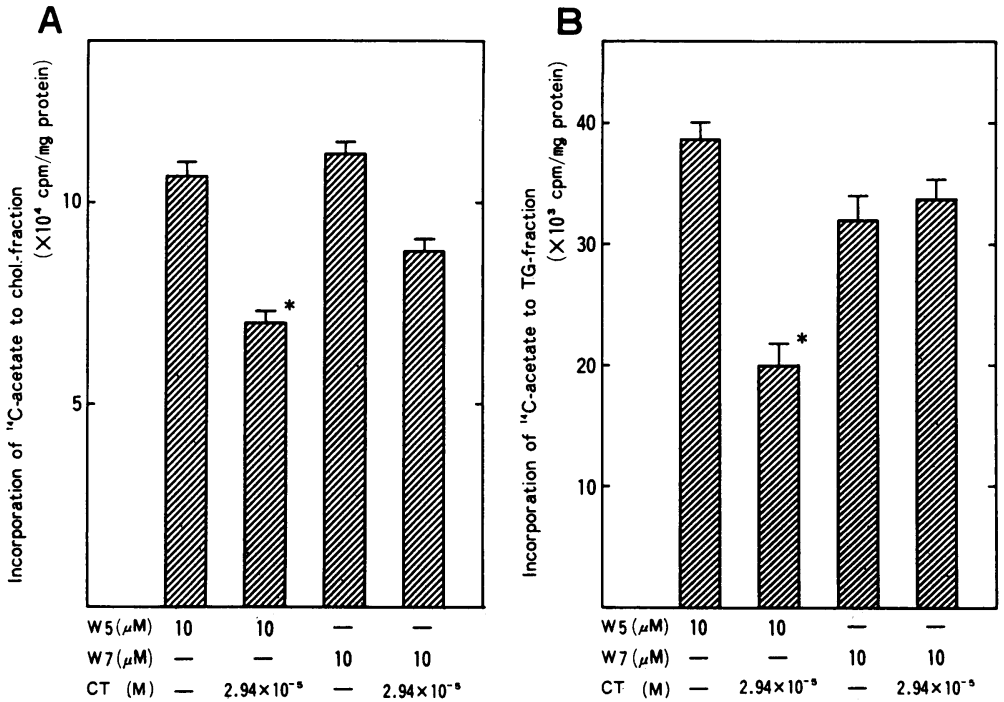

Figure 7. Effect of calcitonin and $\mathrm{W} 7$ on lipid synthesis from $\left[{ }^{14} \mathrm{C}\right]$ acetate in rat hepatocytes with $2 \mathrm{~h}$ of incubation. W7 or W5 was added $1 \mathrm{~h}$ before the incubation with calcitonin began. $(A)$ Cholesterol synthesis. $(B)$ Triglycerides (TG) synthesis. There was significant interaction $(P<0.01)$ for TG synthesis between calcitonin and W7 by analysis of variance. ${ }^{*} P<0.05$ compared with the control by multiple comparison (Scheffe type), Values were by triplicate assays. did not block the effects of calcitonin on CM and FFA, but it did block the effect on LDL and VLDL. There should be at least two different mechanisms for the hypolipidemic effect by calcitonin, one in which W7 has no effect, and a calcium/calmodulin-dependent mechanism.

Calcitonin has cAMP-dependent effects on bone resorption in the rat (40), the transport of calcium in the thick ascending-limb renal tubules of rabbits (41), and the reabsorption of calcium in the cortical thick ascending limb of Henle or distal segment of rat kidney, as do both PTH and glucagon (42, 43). Calcitonin has also been found to have antilipolytic effects in slices of rat fat pad at basal levels or levels slightly stimulated by PTH, noradrenaline, or dibutyryl cAMP; these effects of calcitonin are mediated by a cAMP-dependent mechanism (13). FFA was decreased by calcitonin, and the mechanism of the lipolytic action did not involve the calcium/calmodulinmediated system here, which demonstrates that calcitonin has a cAMP-dependent effect on lipolysis. However, there is no evidence that the decrease in $\mathrm{CM}$ caused by calcitonin involves a cAMP-dependent pathway. There is another possibility that the decreased level of FFA induced by calcitonin is responsible for the reduced synthesis of triglycerides, because FFA is a major substrate for the lipids. This possibility, however, can-

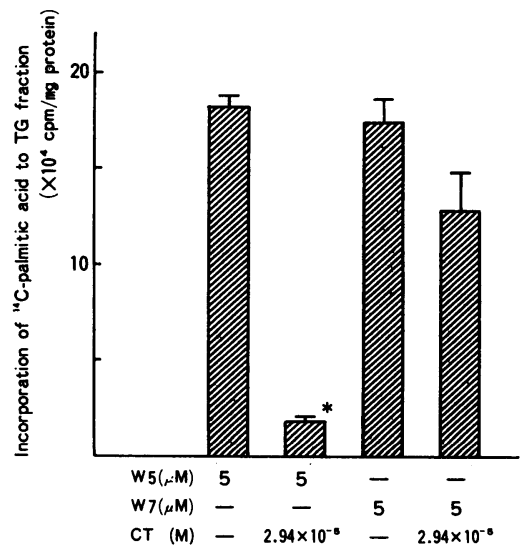

Figure 8. Effect of calcitonin and $\mathrm{W} 7$ on synthesis of triglycerides (TG) from $\left[{ }^{14} \mathrm{C}\right]$ palmitate in rat hepatocytes with $2 \mathrm{~h}$ of incubation. There was significant interaction $(P$ $<0.01$ ) for TG synthesis between calcitonin and $\mathrm{W} 7$ by analysis of variance, ${ }^{*} P<0.025$ compared with the control by multiple comparison (Scheffe type). Values were by triplicate assays. not be used to explain the decrease in CM, because the rats were starved, and few CM could have been synthesized in their intestinal tracts.

The liver is another target organ for calcitonin, and its calcium and phosphate levels are increased in rats by calcitonin $(44,45)$. In rat hepatocytes, calcitonin affects glucose production and the metabolism of amino acids. Hepatocytes have receptors for calcitonin $(12,46)$. In our in vitro study, we focused on the effect of calcitonin on lipogenesis in hepatocytes to examine the calcium/calmodulin-mediated mechanism of calcitonin, especially in the esterification of triglycerides. No evidence was found in these cells of a cAMP-dependent pathway or of any association of the hypolipidemic effect of calcitonin with PI turnover.

Calcitonin accelerates glucose production in the liver (14), which may decrease the amount of substrate such as pyruvate and acetyl Co A for fatty acid synthesis; the decreased amount of substrates probably results in the suppressed synthesis of fatty acids. Calcitonin also promotes the conversion of alanine to pyruvate (47), probably by the direct, calmodulin-independent action of calcium ion, so increased gluconeogenesis is one possible mechanism for the decrease in triglycerides caused by calcitonin, although not the major mechanism.

Calcium has many biological effects on the permeability of membranes by ions, promotion of enzyme activity, control of microtubules, secretion of hormones, and other effects in muscle cells and neurons (48). In kidney or liver cells, a transient but rapid influx of calcium into the cell occurs when the cell is stimulated by an appropriate hormone, such as glucagon or PTH (48). Calcitonin inhibits the outflow of calcium from bone (49), kidney (50), and liver cells (14). An outflow of calcium is, in general, involved with the activity of calciumATPase, which is lowered by calcitonin. Calcitonin presumably increases the intracellular concentration of calcium ion. In this study, we considered two kinds of inhibition of lipogenesis caused by calcitonin in the hepatocytes, that which is dependent on calcium ion in the medium and that which is independent of it. In the former, calcitonin works with extracellular calcium ion to inhibit lipogenesis, and in the latter, calcitonin rearranges the intracellular shift of calcium ion. 
Inaba et al. (51) have reported that calcitonin stimulates phosphorylation of two liver cytosolic proteins with molecular weights of 67,000 and 93,000 . Stimulation of phosphorylation of the $93,000-M_{r}$ protein by calcitonin depends on calcium ion but not on CAMP, and is inhibited by W7. The study suggested that there is a calcium/calmodulin-mediated mechanism induced by calcitonin in the liver. In this study, we confirmed that the concentration of calcium in the medium is associated with lipogenesis caused by calcitonin and that calmodulin inhibitor blocks this effect, so the effect of calcitonin may be mediated by a calcium/calmodulin pathway. Calcitonin probably suppresses lipogenesis in the hepatocytes directly through the increase in intracellular calcium, the increased influx and decreased efflux of calcium, and the intracellular shift from mitochondria to the cytosol, which may shift intracellular calcium-binding protein, calmodulin, and other calcium-binding proteins without changes in cAMP or the PI turnover.

Endocytosis of lipids and lipoproteins and calcium mineralization occur in the final stage of the formation of atherosclerotic plaques $(52,53)$. Several calcium ion antagonists suppress experimental atherogenesis (54-56). In addition to other calcium-related agents like Mg-EDTA (57), chondroitin sulfate A (58), and reserpine (59), calcitonin (60) could be a candidate for use as an antiatherogenic drug.

\section{References}

1. Sinha, T. K., P. Thajchayapong, S. F. Queener, D. O. Allen, and N. H. Bell. 1976. On the lipolytic action of parathyroid hormone in man. Metab. Clin. Exp. 25:251-260.

2. Taniguchi, A., K. Kataoka, T. Kono, F. Oseko, H. Okuda, I. Nagata, and H. Imura. 1987. Parathyroid hormone-induced lipolysis in human adipose tissue. J. Lipid Res. 28:490-494.

3. Hallberg, D., and S. Werner. 1977. Circulatory and lipolytic effects of parathyroid hormone: an experimental study in dogs. Horm. Metab. Res. 9:424-428.

4. Notario, A. 1956. Ormone paratirodeo e ricambio lipidico. Arch. Sci. Med. 5:484-490.

5. Paloyan, E., J. Kolar, J. Castles, D. Paloyan, and P. V. Harper. 1963. The role of the parathyroids in lipid metabolism. Fed. Proc. 22:676.

6. Drueke, T., and B. Lacour. 1985. Parathyroid hormone and hyperlipemia of uremia. Contrib. Nephrol. 49:12-19.

7. Nishizawa, Y., T. Miki, Y. Okui, Y. Matsushita, T. Inoue, and H. Morii. 1986. Deranged metabolism of lipids in patients with chronic renal failure: possible role of secondary hyperparathyroidism. Jpn. J. Med. 25:40-45.

8. Roos, B. A., J. A. Fischer, W. Pignat, C. B. Alander, and L. G. Raisz. 1986. Evaluation of the in vivo and in vitro calcium-regulation of noncalcitonin peptides produced via calcitonin gene expression. Endocrinology. 118:46-51.

9. Tschopp, F. A., H. Henke, J. B. Petermann, P. H. Tobler, R. Janzer, T. Hokfelt, J. M. Lundberg, C. Cuello, and J. A. Fischer. 1985. Calcitonin gene-related peptide and its binding sites in the human central nervous system and pituitary. Proc. Natl. Acad. Sci. USA. 82:248-252.

10. Goltzman, D., and J. Mitchell. 1985. Interaction of calcitonin gene-related peptide at receptor site in target tissues. Science (Wash. DC). 227:1343-1345.

11. Nakamuta, H., Y. Fukuda, M. Koida, N. Fujii, A. Otaka, S. Funakoshi, H. Yajima; N. Mitsuyasu, and R. C. Orlowski. 1986. Binding sites of calcitonin gene-related peptide (CGRP): abundant occurrence in visceral organs. Jpn. J. Pharmacol. 42:175-180.

12. Wimalawansa, S. J., P. C. Emson, and I. MacIntyre. 1987. Regional distribution of calcitonin gene-related peptide and its specific binding sites in rats with particular reference to the nervous system. Neuroendocrinology. 46:131-136.

13. Werner, S., and H. Low. 1974. Inhibitory effects of calcitonin on lipolysis and ${ }^{47}$ calcium accumulation in rat adipose tissue in vivo. Horm. Metab. Res. 6:30-36.

14. Yamaguchi, M., and J. R. Williamson. 1983. Stimulatory effect of calcitonin on calcium uptake and glucose production in isolated rat hepatocytes. Horm. Metab. Res. 15:176-180.

15. Moriguchi, H., J. Yamakawa, M. Inaba, N. Hamada, Y. Nishizawa, and H. Morii. 1982. Effect of calcitonin on amino acid metabolism. Am. Soc. Bone Min. Res. S20. (Abstr.)

16. Weisbrode, S. E., and C. C. Capen. 1974. Ultrastructural evaluation of calcitonin on bone in thyroparathyroidectomized rats administered vitamin D. Am. J. Pathol. 77:455-464.

17. Baud, C. A., and G. Boivin. 1978. Effects of hormones on osteocyte function and perilacunar wall structure. Clin. Orthop. Relat. Res. 136:270-281.

18. Aurbach, G. D., and D. A. Heath. 1974. Parathyroid hormone and calcitonin regulation of renal function. Kidney Int. 6:331-345.

19. Cooper, C. W., J. F. Obie, A. R. Hughes, D. L. Margules, and J. J. Flynn. 1983. Secretion of calcitonin in the genetically obese Zucker rat (fa/fa). Proc. Soc. Exp. Biol. Med. 173:48-55.

20. Margules, D. L., J. J. Flynn, J. Walker, and C. W. Cooper. 1979. Elevation of calcitonin immunoreactivity in the pituitary and thyroid glands of genetically obese rats (fa/fa). Brain Res. Bull. 4:589591.

21. Zucker, L. M. 1965. Hereditary obesity in the rat associated with hyperlipemia. Ann. NY Acad. Sci. 131:447-458.

22. Watanabe, Y. 1980. Serial inbreeding of rabbits with hereditary hyperlipidemia (WHHL-rabbit). Atherosclerosis. 36:261-268.

23. Bagdade, J. D., E. Yee, D. E. Wilson, and E. Shafrir. 1978. Hyperlipidemia in renal failure: studies of plasma lipoproteins, hepatic triglyceride production, and tissue lipoprotein lipase in a chronically uremic rat model. J. Lab. Clin. Med. 91:176-186.

24. Nishizawa, Y., and G. A. Bray. 1978. Ventromedial hypothalamic lesions and the mobilization of fatty acids. J. Clin. Invest. 61:714-721.

25. Nishizawa, Y., and G. A. Bray. 1980. Evidence for a circulating ergostatic factor: studies on parabiotic rats. Am. J. Physiol. 239:R344R351.

26. Horiuchi, Y., T. Nakamura, and A. Ichihara. 1982. Role of serum in maintenance of functional hepatocytes in primary culture. $J$. Biochem. (Tokyo). 92:1985-1994.

27. Nakamura, T., K. Yoshimoto, K. Aoyama, and A. Ichihara. 1982. Hormonal regulations of glucose-6-phosphate dehydrogenase and lipogenesis in primary culture of rat hepatocytes. J. Biochem. (Tokyo). 91:681-693.

28. Billah, M. M., and R. H. Michell. 1979. Phosphatidylinositol metabolism in rat hepatocytes stimulated by glycogenolytic hormones: effects of angiotensin, vasopressin, adrenaline, ionophore A23187 and calcium-ion deprivation. Biochem. J. 182:661-668.

29. Murase, T., D. C. Cattran, B. Rubenstein, and G. Steiner. 1975. Inhibition of lipoprotein lipase by uremic plasma. A possible cause of hypertriglyceridemia. Metab. Clin. Exp. 24:1279-1286.

30. Huttunen, J. K., A. Pasternack, T. Vattinen, C. Ehnholm, and A. Nikkila. Lipoprotein metabolism in patients with chronic uremia. Acta Med. Scand: 204:211-218.

31. Staprans, I., J. M. Felts, and B. Zacherle. 1979. Apoprotein composition of plasma lipoproteins in uremic patients on hemodialysis. Clin. Chim. Acta. 93:135-143.

32. Appelbaum-Bowden, D., A. P. Goldberg, and W. R. Hazzard. 1979. Evidence for a role for hepatic lipase in lipoprotein metabolism. Metab. Clin. Exp. 28:917-924.

33. Bray, G. A., and Y. Nishizawa. 1978. Ventromedial hypothalamus modulates fat mobilization during fasting. Nature (Lond.). 274:900-902.

34. Bray, G. A., and D. A. York. 1979. Hypothalamic and genetic 
obesity in experimental animals: an autonomic and endocrine hypothesis. Physiol. Rev. 59:719-809.

35. Bray, G. A., S. Inoue, and Y. Nishizawa. 1981. Hypothalamic obesity. The autonomic hypothesis and the lateral hypothalamus. Diabetologia. 20:366-377.

36. Schemmel, R., O. Mickelsen, and J. L. Gill. 1970. Dietary obesity in rats: body weight and body fat accretion in seven strains of rats. J. Nutr. 100:1041-1048.

37. Inoue, S., A. Campfield, and G. A. Bray. 1977. Comparison of metabolic alterations in hypothalamic and high fat diet-induced obesity. Am. J. Physiol. 233:R162-R168.

38. Kita, T., M. S. Brown, Y. Watanabe, and J. L. Goldstein. 1981. Deficiency of low density lipoprotein receptor in liver and adrenal gland of the WHHL rabbit, an animal model of familial hypercholesterolemia. Proc. Natl. Acad. Sci. USA. 78:2268-2272.

39. Attie, A. D., R. C. Pitman, Y. Watanabe, and D. Steinberg. 1981. Low density lipoprotein receptor deficiency in cultured hepatocytes of the WHHL-rabbit: further evidence of two pathways for catabolism of exogenous protein. J. Biol. Chem. 256:9789-9792.

40. Heerche, J. N. M., M. P. M. Ng, and B. Heybore. 1978. Hormone-specific suppression of adenosine-3',5'-monophosphate responses in bone in vitro during prolonged incubation with parathyroid hormone, prostaglandin $\mathrm{E}_{1}$, and calcitonin. Endocrinology. 103:333340.

41. Suki, W. N., and D. Rouse. 1981. Hormonal regulation of calcium transport in thick ascending limb renal tubules. Am. J. Physiol. 241:F171-F174.

42. Torikai, S., M. S. Wang, K. Klein, and K. Kurokawa. 1981. Adenylate cyclase and cell cyclic AMP of rat cortical thick ascending limb of Henle. Kidney Int. 20:649-654.

43. Morel, F., D. Chabrardes, M. Imbert-Teboul, F. Le Bouffant, A. Hus-Citharel, and M. Montegut. 1982. Multiple hormonal control of adenylate cyclase in distal segments of the rat kidney. Kidney Int. 21(Suppl. 11):S55-S62.

44. Meyer, R. A., Jr., and M. H. Meyer. 1975. Thyrocalcitonin injection to rats increases the liver inorganic phosphate. Endocrinology. $96: 1048-1050$.

45. Yamaguchi, M., Y. Takei, and T. Yamamoto. 1975. Effect of thyrocalcitonin on calcium concentration in liver of intact and thyroparathyroidectomized rats. Endocrinology. 96:1004-1008.

46. Yamaguchi, $\mathrm{M}$., and $\mathrm{M}$. Ito. 1985. Regulation of $\left(\mathrm{Ca}^{2+}-\mathrm{Mg}^{2+}\right)-$ ATPase activity by calcitonin binding to rat liver plasma membranes. Acta Endocrinol. 110:124-129.
47. Yamaguchi, M. 1981. Calcitonin stimulates glycogenolysis in the liver of fasted rats. Endocrinol. Jpn. 28:643-646.

48. Rasmussen, H., and D. B. P. Goodman. 1977. Relationships between calcium and cyclic nucleotides in cell activation. Physiol. Rev. 57:421-509.

49. Harell, A., I. Binderman, and G. A. Rodan. 1973. The effect of calcium concentration on calcium uptake by bone cells treated with thyrocalcitonin (TCT) hormone. Endocrinology. 92:550-555.

50. Borle, A. B. 1969. Effects of thyrocalcitonin on calcium transport in kidney cells. Endocrinology. 85:194-199.

51. Inaba, M., H. Morii, Y. Nishizawa, T. Miki, T. Yukioka, S. Morisawa, and A. Inoue. 1986. Calcitonin-induced phosphorylation of rat liver cytosolic proteins. J. Biochem. (Tokyo). 100:591-595.

52. Ross, R., and J. A. Glomset. 1976. The pathogenesis of atherosclerosis. N. Engl. J. Med. 295:369-377.

53. Yu, S. Y., and H. T. Blumenthal. 1978. The calcification of elastic fibers. I. Biochemical studies. J. Gerontol. 18:119-126.

54. Kramsch, D. M., Aspen, A. J., and C. S. Aspen. 1980. Suppression of experimental atherosclerosis by the $\mathrm{Ca}^{++}$-antagonist lanthanum. Possible role of calcium in atherogenesis. J. Clin. Invest: 65:967-981.

55. Henry, P. D., and K. I. Bentley. 1981. Suppression of atherogenesis in cholesterol-fed rabbit treated with nifedipine. J. Clin. Invest. 68:1366-1369.

56. Rouleau, J. L., W. W. Parmley, J. Stevens, J. Wikman-Coffelt, R. Sievers, R. W. Mahley, and R. J. Havel. 1983. Verapamil suppresses atherosclerosis in cholesterol-fed rabbits. J. Am. Coll. Cardiol. 1:1453-1460.

57. Wartman, A., T. L. Lampe, D. S. McCann, and A. J. Boyle. 1967. Plaque reversal with Mg-EDTA in experimental atherosclerosis: elastin and collagen metabolism. J. Atheroscler. Res. 7:331-341.

58. Morrison, I. M., G. S. Bajwa, R. B. Alfin-Slater, and B. H. Ershoff. 1972. Prevention of vascular lesions in the coronary artery and aorta of rat induced by hypervitaminosis $\mathrm{D}$ and cholesterol-containing diet. Atherosclerosis. 16:105-108.

59. Whittington-Coleman, P. J., and O. Carrier, Jr. 1970. Effects of agents altering vascular calcium in experimental atherosclerosis. Atherosclerosis. 12:15-26.

60. Robert, A. M., M. Moczar, D. Brechemier, G. Godeau, M. Miskulin, and L. Robert. 1978. Biosynthesis and degradation of matrix macromolecules in the arterial wall. Regulation by drug action. Rheinisch-Westfoel. Akad. Wiss. Nat. Ing. Wirtschaftswiss. Vortr. 301-321. 